\title{
Antitumoral effect of farnesiltransferase and mtor inhibitors in hepatocellular carcinoma: in vitro studies
}

\author{
Ana M Araújo ${ }^{1 *}$, Sílvia S Neves², Ana L Ferreira', Diogo Branco ${ }^{1}$, Ana B Sarmento-Ribeiro ${ }^{1,2}$, \\ José M Nascimento-Costa ${ }^{1,2,3}$ \\ From 16th International Charles Heidelberger Symposium on Cancer Research \\ Coimbra, Portugal. 26-28 September 2010
}

Hepatocellular carcinoma (HCC) is one of the most common cancers worldwide, often diagnosed at an advanced stage when the most potentially curative strategies are no longer effective. Advances in the understanding of tumor biology are opening new paths for the prevention and treatment of HCC, through the development of new targeted therapies. The design of drugs that block different growth-promoting pathways, activate apoptotic pathways may also open new horizons in the treatment of HCC.

The aim of this study was to test the efficacy of new targeted drugs involved in signalling pathways, such as farnesiltransferase (L-744832) and mTOR inhibitors (everolimus) in a HCC cell line (HUH-7 cells).

The HUH-7 cells were cultured in absence and presence of diferent concentrations of L-744832 and everolimus. The antiproliferative effect was assessed by the Alamar Blue assay and cell death by optic microscopy and flow cytometry.

Our results showed that farnesiltransferase and mTOR inhibitors had an antiproliferative and cytotoxic effects in monotherapy in a dose and time dependent manner, inducing cell death preferentially by apoptosis. On, the other hand, the combination of L-744832 and everolimus with conventional anticarcinogenic drugs demonstrated a higher antiproliferative and cytotoxic effect for lower doses than the IC50 used in monotherapy (addition or potentiation synergism).

These results suggested that farnesiltransferase and mTOR inhibitors may constitute a new potential

\footnotetext{
* Correspondence: anamfa@gmail.com

${ }^{1}$ Faculty of Medicine, University of Coimbra (FMUC), Coimbra, Portugal
}

Full list of author information is available at the end of the article therapeutic approach in HCC either in monotherapy or in association with conventional therapies.

\section{Author details}

${ }^{1}$ Faculty of Medicine, University of Coimbra (FMUC), Coimbra, Portugal. ${ }^{2}$ Center of Investigation on Environment, Genetics and Oncobiology (CIMAGO), FMUC, Coimbra, Portugal. ${ }^{3}$ Medicine Service and Hepatology Unit, University Hospital of Coimbra, Coimbra, Portugal.

Published: 24 September 2010

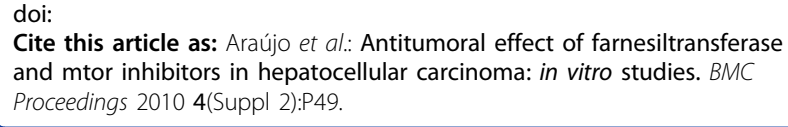

Cite this article as: Araújo et al:: Antitumoral effect of farnesiltransferase and mtor inhibitors in hepatocellular carcinoma: in vitro studies. BMC Proceedings 2010 4(Suppl 2):P49.

Submit your next manuscript to BioMed Central and take full advantage of:

- Convenient online submission

- Thorough peer review

- No space constraints or color figure charges

- Immediate publication on acceptance

- Inclusion in PubMed, CAS, Scopus and Google Scholar

- Research which is freely available for redistribution

Submit your manuscript at www.biomedcentral.com/submit
C Biomed Central 